\title{
東京都美術館の建築プロセスにおける設計内容の確定過程 DECISION MAKING PROCESS OF DESIGN CONTENTS IN TOKYO METROPOLITAN ART MUSEUM
}

\author{
西野佐弥香*1, 高松 伸*2, 古阪秀三*3, 平野吉 信*4 \\ Sayaka NISHINO, Shin TAKAMATSU, Shuzo FURUSAKA \\ and Yoshinobu HIRANO
}

\begin{abstract}
Today, there are some problems in construction projects, for example, insufficient communication between designers and constructers, confusion about roles and responsibilities, and so on. On the other hand, in these days, designers and constructers had close communication and realized high quality buildings in many projects. This study aims to show a decision making process of design contents in such projects. As a typical one, this study deals with Tokyo Metropolitan Art museum designed by Mayekawa Associates, Architects \& Engineers, based on interviews to parties and examinations of drawings and specifications and shop drawings.
\end{abstract}

Keywords: Design Intentions, Design Contents, Decision Making Process, Drawings and Specifications, Shop Drawings 設計意図，設計内容，確定過程，設計図書，施工図

\section{1.はじめに}

\section{$1-1$ 研究の背景と目的}

今日の建築プロジェクトにおいて、工事段階における設計や、施 工計画などを通じて確定されるべき設計内容における深刻な不整合 が露呈し、品質に関する問題が発生している。その背景として、例 えば、設計図書の内容が十分でないこと、関係者間の意思疎通が満 足に行われていないこと、伝えるべき設計意図注1)とは何かが曖昧で あり、工事段階における設計者・工事監理者などの役割と責任が混 乱していることなどが指摘されている注2)。本研究は、上記の状況に 対し、建物の完成度を高めるための一つの要因として、建築プロセ スにおける建築プロジェクトの参加者間の連携に着目し、設計者の 施工者との連携を中心に検討しようとするものである。本稿は、そ の第一段階として、現在の建築プロジェクトにおける指導的な立場 の者が影響を受け、業務のやり方や考え方を学んだであろう時代の 建築家が主導した建築プロジェクトを対象とし、設計者と施工者を はじめとする様々な主体の連携により建築プロセスが進められるさ まを、実証的に記述することを目的とする。そのために、前川國男 建築設計事務所（現前川建築設計事務所、以下、前川事務所）の設 計による東京都美術館（1975）を対象として取り上げる。

\section{$1-2$ 先行研究}

\section{1-2-1＼cjkstart建築生産システムの脆弱性と品質確保}

建築生産システムの脆弱性と品質確保のしくみについて扱った主 な先行研究として、高麗 ${ }^{1)}$ 、平野 ${ }^{2)}$ 、古阪 ${ }^{3)}$ の研究などが挙げられる。 これらに対し、本研究は、これらの扱う実態を問題意識としながら も、現代とは異なる建築プロジェクトについての実態を示す。

\section{1-2-2＼cjkstart建築プロジェクトにおける情報の確定過程}

建築プロジェクトにおける情報の確定過程に関する主な先行研究 として、峰政による一連の研究 ${ }^{4}$ がある。これらは、生産情報が工 事段階で多数の主体の協㗢により確定していくプロセスを扱ったも のであり、建築プロジェクトにおける生産情報の確定支援方法を提 案することを目的としている。これに対し、本研究は、設計者を軸 に、設計段階も含めた建築プロセスを扱う。

\section{2. 研究の方法}

\section{2-1 研究対象の選定}

本稿では、建築プロセスを実証的に記述するため、研究対象の選 定にあたり、次の 2 点を重視した。(1)保存されている資料が豊富で、 利用可能であること、(2)プロジェクトに参加した設計者と施工者双 方の協力が得られ、充分なヒアリングが可能であること。東京都美 術館はこれらの 2 点を満たし、本章第 3 節に示寸資料調査ならびに
*1 京都大学工学研究科建築学専攻 博士課程 $\cdot$ 工修

*2 京都大学工学研究科建築学専攻 教授 . 博士 (工学)

*3 京都大学工学研究科建築学専攻 准教授. 工博

*4 広島大学工学研究科社会環境システム専攻 教授・博士 (工学)
Graduate Student, Dept. of Architecture and Architectural Eng., Kyoto Univ., M. Eng.

Prof., Dept. of Architecture and Architectural Eng., Kyoto Univ., Dr. Eng.

Assoc. Prof., Dept. of Architecture and Architectural Eng., Kyoto Univ., Dr. Eng.

Prof., Dept. of Social and Environmental Eng., Hiroshima Univ., Dr. Eng. 
第 4 節に示すヒアリング調査の実施が可能であった。

\section{2-2 文献調査}

研究対象についての背景の把握や現在と異なる状況の理解のため、 主に下記の 2 点について文献調查を行った。第一に、東京都美術館 と前川國男についてである。第二に、実務者による情報伝達につい ての検討である。

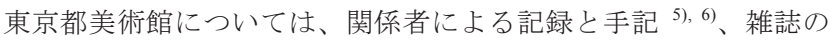
掲載記事 7)などがある。前川に関する主要な文献としては、前川本 人の文集 ${ }^{8), 9}$ 、作品集 ${ }^{10)}$ 、ディティール集 ${ }^{11)}$ 、設計図集 ${ }^{12)}$ 、評伝 ${ }^{13) \sim 15)}$ などのほか、多くの雑誌の掲載記事があり、前川の作品、設計手法、 思想、言説などが取り上げられてきた。一方で、前川に関する学術 論文は、まだ充実しているとは言い難い注3)。

日本建築士会連合会と建築業協会の間では、設計と施工をめぐる 問題の解決のための協調的取り組みにより、発注者・設計者・施工 管理者・専門工事業者の共通言語が提案された ${ }^{16) 20)}$ 。また、日本建 築家協会では、設計段階から工事段階にかけての情報伝達が、設計 図から施工図への展開を焦点として検討された ${ }^{21)}$ 。

\section{$2-3$ 関連資料の収集と分析}

以下の資料を対象とし、資料の収集と分析を行った。前川事務所 が保管していた資料として、(1)特記仕様書、(2)設計変更図・追加発 行図、(3)施工図、(4)工事データー 東京都美術館、施工管理を担当 した大林組が保管していた資料として、(1)契約図【意匠、構造】、(2) 東京都美術館改築工事施工記録、(3)工事記録概要書、(4)工程表【実 施工程表、月間工程表、週間工程表】

\section{2-4 関係者へのヒアリング調査}

東京都美術館の設計の担当者、施工の担当者を対象とし、資料の 位置づけ、資料に記録されていない業務や役割を把握するためにヒ アリング調查を行った注4)。事実に即した正確な記述を行い、より詳 細な事実を把握するため、ヒアリングで把握した内容を資料調査の 結果と合わせて建築プロセスや設計内容の確定過程について図化し、 それをフィードバックして再度ヒアリングを行うことを繰り返した 注5)。また、前川事務所ならびに大林組のそれぞれに所属する、同時 代のプロジェクトの参加者にアドバイザーとして臨席いただき、よ り多角的にプロジェクトを捉える工夫をした。

\section{3. 研究対象の概要}

\section{3-1 前川國男建築設計事務所}

前川事務所の創立者前川國男（1905 1986）は、日本の近代を代 表する建築家の一人である。数多くの建築を設計し注 6 、現在まで使 用されているものが多数ある。第 1 回建築学会大賞 (1968)、5 度の 日本建築学会賞注 7) など多数の受賞歴を持つ。また、建築家の職能 についても積極的に発言し、日本建築家協会会長（1959 1962）、UIA 副会長（1965 1969）などを歴任した。

特徵的な設計の方法のひとつに、「テクニカルアプローチ」 ${ }^{22)}$ と称 される、建築における基礎的な技術の開発とその共有を推し進める こと、同時に、そのことを通して、造形的には禁欲的で潔癖なデザ インを試みること」 ${ }^{23)}$ がある。その成果として、専門工事業者との 協働により、打込みタイル、耐候性鋼、PC（プレキャスト・コンク リート）などが開発された。また、構造設計については、長年にわ たり、横山建築構造設計事務所（以下、横山事務所）と協働してい る。

\section{3-2 東京都美術館}

東京都美術館（建築プロセスを表 1 に、概要を表 2 に示す）は前 川國男の円熟期の建築であり、その建築プロセスでは、前川事務所 の業務や体制がほぼ確立されていた。「テクニカル・アプローチ」の 代表である打込みタイル、耐候性鋼、プレキャスト・コンクリート の3つが共に用いられた。これらに関する技術やディティールは、 過去のプロジェクトにより大部分が蓄積されていた。1976 年に第 17 回 BCS 賞 (建築業協会賞) を受賞し、施工に対する評価も高い。2010 年から改修工事が行われ、竣工から 35 年経った後も、継続して使用 される予定である。また、前川の発案により、竣工後、発注者・設 計者・施工者を始めとするプロジェクト参加者の集い（銀杏会）が 定期的に継続されていた。

東京都美術館は、旧館が構造及び耐久度上、使用不適格とされた ため、新館として建設された。設計にあたっては、1. 展示された 美術品に対して、あくまで『中立平静』な背景を提供すること、2. 外部環境の疎外をできる限り避けること、3. 耐久性を考慮した素 材および構法によって、『平凡な素材によって、非凡な結果を創出す る』こと、の 3 点がテーマとされた。地上階のエスプラナードから 導かれる、主階の地下 1 階の広場とエントランスロビー、その下の 大彫塑室と小彫塑室を全体の構成上・動線上の大きな軸として、連 続するアーチが設けられた。公募展示棟、企画展示棟、文化活動棟 がその周りに配置され、外装には打込みタイル、金属部分には耐候 性鋼が用いられた。

表 1 東京都美術館の建築プロセス

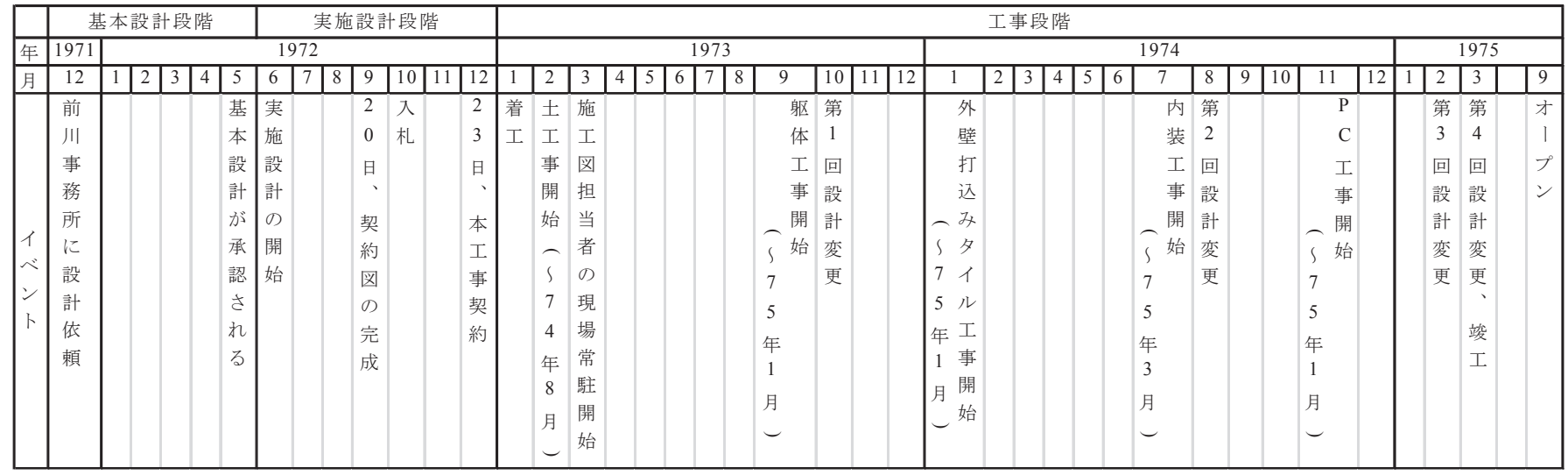


表 2 東京都美術館の概要

\begin{tabular}{|c|c|}
\hline 所在地 & 東京都台東区上野公園 8 番 36 号 \\
\hline 発注者 & 東京都 \\
\hline $\begin{array}{l}\text { 設計監理 } \\
\text { 注 8) }\end{array}$ & 前川國男建築設計事務所, 横山建築構造設計事務所 \\
\hline 監理 & 東京都教育庁社会教育部文化課 \\
\hline 施工 & $\begin{array}{l}\text { 建築／大林組, } \\
\text { 空調設備／大気社, 衛生設備, 西原衛生工業所, } \\
\text { 電気設備 } / \text { 関東電気工事, エレベーター設備／東京芝浦電気 }\end{array}$ \\
\hline 敷地面積 & $16,060.0 \mathrm{~m}^{2}$ \\
\hline 建築面積 & $6,755.94 \mathrm{~m}^{2}$ \\
\hline 延床面積 & $31,943.48 \mathrm{~m}^{2}$ \\
\hline 階数 & 地下 3 階, 地上 2 階, 塔屋 1 階 \\
\hline 構造 & 鉄筋コンクリート造一部鉄骨造 \\
\hline
\end{tabular}

\section{4. 建築プロセスを通した設計内容の確定過程}

\section{$4-1$ 基本設計段階（1971 年 12 月～1972 年 5 月）}

\section{4-1-1 概要}

1971 年 12 月に、同じ上野公園内の東京文化会館の設計を担当し た前川事務所に設計が依頼され、基本設計契約が結ばれた。基本設 計段階における設計内容は、基本設計説明書にまとめられ、工事費 の概算が出された。ヒアリングにおける、利用者（公募展を主催す る美術団体）の了解を経て、1972 年 5 月に発注者が基本設計を承認 した。

\section{4-1-2 体制}

基本設計の開始にあたり、前川國男が前川事務所の所員 2 名（以 下、それぞれを A1、A2 とする）をプロジェクトのコアスタッフと して指名した。A1、A2 は同時に同じ図面に取り組み、与条件を考 慮しながらアイディアを出し合って設計を進めた。

構造設計は横山事務所が担当し、この段階から設計に参加した。 なお、前川事務所と横山事務所は同じ建物（MID ビル、東京都新宿 区）内にあり、前川事務所の多くのプロジェクトにおける構造設計 を横山事務所が担当している。設備と構造の取り合いなど、設計上 の統括は前川事務所が担った。

\section{4-1-3 設計内容の確定}

(1) 与条件として、『常設・企画機能』、公募団体の要請に応えうる 『新作発表機能』、『文化活動機能』が求められた。新館全体の床 面積は旧館の 2 倍近くなる一方、様々な制限から、延床面積の 60 パーセント近くが地下に設けられることになった。美術団体に対 してもヒアリングが行われ、大手美術団体 4 団体が、同時期に同 等の展示室においてそれぞれ公募展を行えること、それが 8 団体、 12 団体となっても可能であることが求められた。

(2) 前川と A2 が敷地の見学を行い、公募棟を始めとして、企画展 棟、文化管理棟の配置を検討した。

(3) A1、A2 により、ボリュームの検討、主なゾーニング、動線計 画が行われ、公募展を実施する際の搬入、荷解き、審查、展示、 荷造り、搬出の際の流通ルートが検討された。これらは A1、A2 が共に図面を作成し、それをさらに前川が確認・検討することで 設計が進められた。前川がスケッチを作成することもあった。外 装を打込みタイルとすること、広場やエントランスロビーにアー チを用いることなども決定された。

(4) A1、A2 が横山事務所と共に柱のスパン、梁成から階高の検討 などを行った。
(5) 基本設計段階における確定内容である、全体計画、動線計画、 一般図、外観図、設備系統図、全体の仕様などは基本設計説明書 にまとめられ、利用者の了解を経て、発注者が承認した。

\section{$4-2$ 実施設計段階（1972 年 6 月～12 月）}

\section{4-2-1 概要}

実施設計契約を経て、実施設計が開始された。実施設計における 設計内容は、契約図書である施工者の指名競争入札用の図面（契約 図）ならびに特記仕様書、確認申請用の図面にまとめられた。

\section{4-2-2 体制}

開館の日程が決まっていて実施設計の期間が限られていたため、 前川事務所では、基本設計段階から参加したコアスタッフの A1 、 A2 に加えて、所内の比較的若手である A3、A4 と、ベテランの A5、 A6 が主となって実施設計を行った。また、所内の設備設計者が加わ ったほか、横山事務所も引き続き参加した。打込みタイルなどの一 部の部位については、専門工事業者も検討に参加した。

前川は $\mathrm{A} 1 、 \mathrm{~A} 2$ とやりとりをして、気になる部分や進捗を見、指 示を出した。A $\mathrm{A}$ と $\mathrm{A} 2$ は共に前川とのやりとり、所内の仕事の割り 振りや工程の管理を行ったほか、A1 は前川事務所内の統括を、A2 は対外的な統括を担った。図面については、A1 は打込みタイルの詳 細図や仕上表などを、A2 は平面詳細図などを、A3、A4 は一般図を 始めとする図面の多くを、A5、A6 は耐候性鋼などの特殊な部位や 難しい納まりなどについての図面を作成した。設備、構造の設計者 とのやりとりは、該当部分を設計している者が行った。

\section{4-2-3 設計内容の確定}

(1) 基本設計をもとにして、A1、A2 が仕上表や詳細図などを作成 すると共に、A1、A2 の指示により、A3、A4 が平面図、立面図、 断面図、矩計図などの一般図、建具表、詳細図などを作成した。

(2) A5、A6 が打込みタイルや耐候性鋼製サッシなど、先行するプ ロジェクトで用いたものについて、ディティールの引き継ぎと改 善を行い、図面にまとめた。

(3) $\mathrm{A} 1$ ～A6 のそれぞれが、設計を担当している部分の必要に応じ て、設備、構造の設計者とのやりとりを行った。

(4) 打込みタイルなど、一部の設計について専門工事業者が検討に 参加し、A1、A2 とやりとりを行った。

(5) 前川が作成された図面を確認・検討して、気になる部分の状況 を A1、A2 にたずね、仕上げの修正などの指示を出した。

(6) 実施設計の途中で作成された図面は、A2 が発注者の内諾を得た

（7) 実施設計における確定内容である、入札ならびに確認申請に必 要な情報は、契約図書と確認申請用の図面にまとめられ、発注者 に提出されて承認を受けた。契約図には、一般図、平面詳細図 $(1 / 100,1 / 50,1 / 20)$ 、矩計詳細図(1/50,1/20)、天井伏詳細図(1/20)、 コア廻りや大小彫塑室釣天井、各部納まりなどの部分詳細図(1/50, 1/20,1/10,1/2)、仕上げなどが入れられた。

\section{$4-3$ 工事段階（1972 年 12 月～1975 年 3 月）}

\section{4-3-1 概要}

実施設計段階で作成された契約図書を用いて指名競争入札が行わ れ、大林組が施工を担当することになった。1972 年 12 月に本工事 契約が結ばれ、前川事務所とは設計監理契約が結ばれた。1973 年 1 月に着工し、同年 2 月に土工事、9 月に躯体工事が開始された。1975 年 3 月に竣工し、同年 9 月に開館した。 


\section{4-3-2 体制}

前川事務所では、設計監理のうち、設計段階から引き続いて事務 所で 行うものを「本社監理」、現場で行うものを「現場監理」とし ている。前川のもとで $\mathrm{A} 1$ と $\mathrm{A} 3$ が「本社監理」を担当し、現場では、 $\mathrm{A} 2$ がチーフとなり、A4、設備の担当者として 1 名注 9)、横山事務所 からは構造の担当者として 1 名の計 4 名が常駐して「現場監理」を 担当した。

「本社監理」では、未確定部分についての詳細設計や設計変更を 行った。A1 は前川や「現場監理」の A2 とのやりとり、現場で行わ れる定例会議への出席を、A3 は A1 からの指示を受けて、A1 とや りとりをしながら図面の作成の多くを担当した。「現場監理」では発 注者との打ち合せ、施工図の検討・承認、施工要領書・施工管理計 画書の承認、指示書の発行などを行った。A2 が発注者とのやりとり、 「本社監理」の A1 とのやりとりや、本社で作成される図面の工事 に間に合うための工程の管理、施工者への指示、施工図の承認など を、A4 が工事監理（図面と工事の照合）を担当した。前川は事務所 での指導のほか、現場での指示、広場のアーチやサッシなどの意匠 上重要な要素に関する最終決定、色決めなどを行った。

大林組は約 30 名が施工管理にあたったほか、施工図担当者 1 名も 1973 年 3 月初頭から現場に常駐し、施工図の作成を行った。東京都 教育庁の担当者が発注者として現場に隣接する旧館に常駐し、打ち 合せへの参加、設計変更の承認などの監理を行った。

\section{4-3-3 設計内容の確定}

(1) 着工してから躯体工事の開始までに、大林組の施工管理者を対 象として設計上の重要な箇所の説明や、施工上の注意など、設計 意図の説明が行われた。

(2) 東京都美術館と同様に打込みタイルを採用した事例として、大 林組の施工管理者を対象として前川事務所が設計した埼玉県立博 物館（1971）の案内が行われ、先行例の見学を通して打込みタイ ルに対する理解が求められた。

（3）発注者が現場に隣接する東京都美術館の旧館に、「現場監理」の 担当者である A2、 $\mathrm{A} 4$ と施工管理者が同じ現場事務所に階を分か れて常駐していたため、日常的に、疑問点や検討す心゙き点が生じ るたびに打ち合わせが行われた。「現場監理」の担当者と施工管理 者の検討の内容は施工図に反映されて共有された。

(4) 工程などについての定例は週 1 回行われ、A2、A4、施工管理者 （設備は別途工事であったので、その施工管理者も含む）、発注者、 「本社監理」の担当者である A1 が参加した。司会、議事録の作 成は $\mathrm{A} 2$ が行った。

(5) 前川のもと、事務所で「本社監理」の担当者（A1、A3）が契約 図では描き切れなかった納まりや材料などの詳細や、確定しなか つた検討部分についての追加発行図、追加・変更部分についての 変更図を作成した。その際、前川の指示により、アーチなどの曲 面の部分について、事務所で $1 / 20$ の模型で検討が行われた。

(6) A2 が、工事に間に合うよう「本社監理」における追加発行図・ 変更図の作成を要請した。

(7) 部屋の用途変更といった発注者からの変更の指示は、A2 に対 して変更指示書により伝達された。

(8) 発注者からの変更の指示は、A2 が A1 に伝え、追加発行図・変 更図の作成を要請した。
（9）１１は現場に指示する事項をまとめ、定例会議の際に新しい図面 を持参して $\mathrm{A} 2$ に伝達し、A2 と打ち合わせ行った。原則的に、前 川が「現場監理」の担当者に指示をしたり、「本社監理」の担当者 が発注者や施工管理者に伝達することはなかった。

(10) A2 が作成された追加発行図・変更図について発注者に説明し て内諾を得、発注者が図面に承認印を押した。例えば便所を身障 者対応にすることなど、図面の作成前に、あらかじめ内諾を得て おくこともあった。

(11) 実際の工事費の変更は、発注者の承認（捺印）のある図面や発 注者からの変更指示書をまとめ、東京都の支払のタイミングに合 わせて、計 4 回の「設計変更」(契約変更) において行った。

(12) (7)、(9)は、A2 が施工管理者に伝達した。指示、追加、変更な どの際には、指示書を出して周知を図った。指示書には発注者、 各施工管理者などの回覧先が記載され、閲覧した者は捺印の上、 控えを取って次に回すようになっていた。発注者からの変更の指 示は、A2 が打ち合わせの際にスケッチや指示書を用いて施工管 理者に伝達した。発行された追加発行図・変更図は、A2 が指示 書にその旨を記載し、見積の依頼などのコメントを加えて図面に 添付し、回覧した。

(13) 大林組の施工図担当者、専門工事業者が契約図書、追加発行図・ 変更図の発行や指示を受けて、施工図を作成した。

(14) A2 が、設計意図が施工図に正確に反映されているかどうかを判 断し、施工図の承認を行った。設計者が「現場監理」の担当者と 同一人物であることにより、このような判断を迅速に下寸ことが 可能であった。原設計図と施工図の照合は、A4 が行った。一部、 耐候性鋼製サッシなどについては、前川が承認を行った。なお、 専門工事業者が作成した施工図は、施工管理者が工事予算に合っ ているかどうかを確認し、それを A2 が承認すると共に、例えば 金額の大きい打込みタイルのような重要な図面は、施工管理者が 発注者の承認も得た。

(15) 承認済みの施工図の原図は原則的に施工管理者が保管し、主に その青図を用いて A2 が発注者ならびに A 1 に経緯を伝えた。一部、 承認前の施工図を $\mathrm{A} 1$ が現場で確認することもあった。

(16) 地下 1 階広場の現場打ちコンクリートによるアーチは、モック アップを前川が承認することで、最終的な設計内容が確定した。 それを大林組の施工図担当者が施工図として起こし、再度、A2 の承認を得た。

(17)色決めは前川が現場で行った。公募展棟のロビーの場合、前川 それぞれの棟について色を決定した。

(18) 当該工事の前に施工者がまとめた施工要領書は、それによって 工事をしたときに設計意図が実現されるかどうかについて A2 が 確認を行い、A2 の承認を経て工事が開始された。事によっては、 横山事務所の「現場監理」の担当者も承認した注 ${ }^{10)}$ 。

(19) 例えばコンクリート打設について、「現場監理」の担当者が施工 の指導を行った。検査願による施工管理者の体制の確認、専門工 事業者の社内検查表による型枠、鉄筋等の検查の確認を行い、打 設の前日には施工管理者や専門工事業者を集め、役割分担、手順 や注意点を周知するためにシミュレーションを行った。打設の当 日は生コンクリートの出庫伝票の確認や打設の指揮を行った。 
以上の建築プロセスにおける体制の推移と設計内容の確定過程を 図表化し、表 3 に各段階で作成された図書の概略、図 1 に建築プロ セスにおける体制、図 2 に設計内容の確定過程の概略、表 4 に各段 階で取られたアクション、そのアクションへの参画主体と各主体の 演じた役割、そのアクションでどのような設計内容が確定したか、 それがどのように伝達・共有されたかを示す。なお、発注者をOW、 前川を $\mathrm{AR}$ 、横山事務所を $\mathrm{Eng}$ 、大林組を $\mathrm{GC}$ 、専門工事業者を $\mathrm{SC}$ として示寸。また、 $\mathrm{A} 1 \sim \mathrm{A} 6$ 、基本設計段階における(1)（5)、実施設 計段階における(1)〜 (7)、工事段階における(1)〜 (19)の番号は、上述の 番号に対応している。
表 3 図書の概略

\begin{tabular}{|c|c|}
\hline $\begin{array}{c}\text { 基本設計説明書 } \\
\text { (基本設計段階) }\end{array}$ & $\begin{array}{l}\left.\mathrm{B} 4 \text { サイズで建築主体の図面 } 12 \text { 枚 }{ }^{\text {注 }} 11\right) \text { (全体計画、 } \\
\text { 動線計画、一般図、外観図、設備系統図、全体の仕 } \\
\text { 様、模型写真) }\end{array}$ \\
\hline $\begin{array}{l}\text { 契約図 } \\
\text { (実施設計段階) }\end{array}$ & $\begin{array}{l}\text { 建築図 } 78 \text { 枚、構造図 } 68 \text { 枚、設備図 } 143 \text { 枚注 } 12) \text { 。 } \\
\text { 札の見積もこの図書で行った。実施設計図書として } \\
\text { は、建築主体の図面が } 101(ら ち \text { 外構 22) 枚、構造 } \\
\text { の図面が } 73 \text { 枚、設備図 } 143 \text { 枚注13)。 }\end{array}$ \\
\hline $\begin{array}{l}\text { 特記仕様書（実施 } \\
\text { 設計段階） }\end{array}$ & $\begin{array}{l}\text { 総則・構造体工事・庁舎等仕上工事の } 3 \text { 編からなる } \\
\text { 建築一般、「外構工事」、「空気調和換気設備工事」、 } \\
\text { 「電気設備工事」、「給排水衛生設備工事」 }\end{array}$ \\
\hline $\begin{array}{l}\text { 追加発行図・変更 } \\
\text { 図 (工事段階) }\end{array}$ & 142 枚注 14)（設計詳細図、一部は設計変更図） \\
\hline $\begin{array}{l}\text { 施工図 } \\
\text { (工事段階) }\end{array}$ & $\begin{array}{l}\text { 杭・躯体図 79、平面他詳細図 18、鉄骨製作図 14、 } \\
\text { 建具製作図 23 (うちシャッター11)、PC 製作図 22、 } \\
\text { タイル工事図 23、仮設工事図 1、その他工事図 29 } \\
\text { の計 } 209 \text { 枚注 15) }\end{array}$ \\
\hline
\end{tabular}
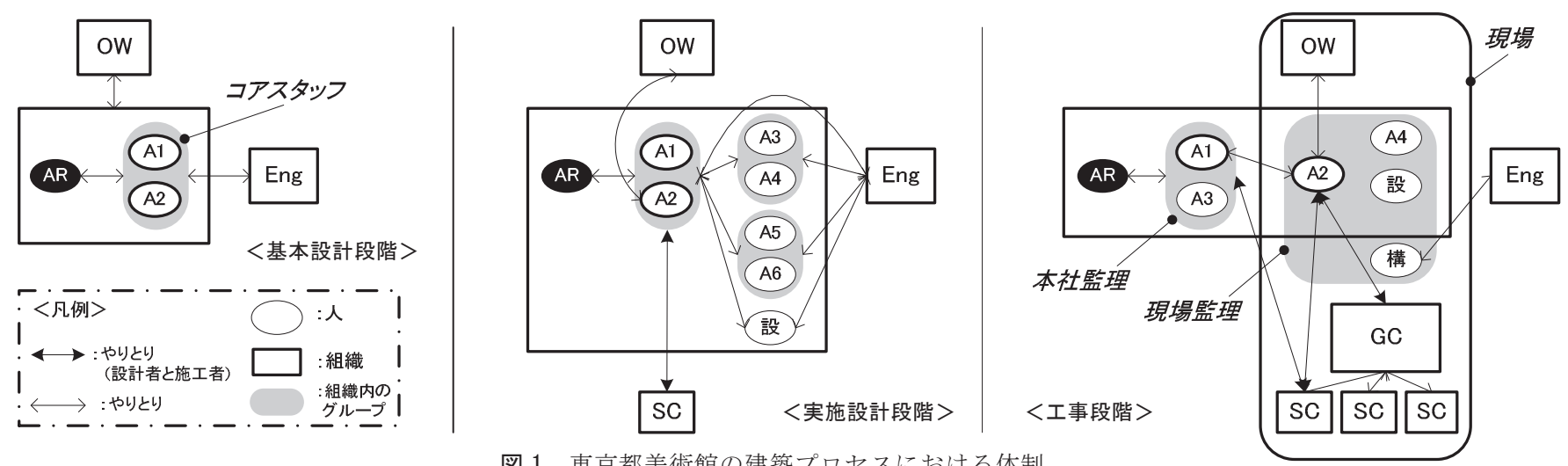

図 1 東京都美術館の建築プロセスにおける体制
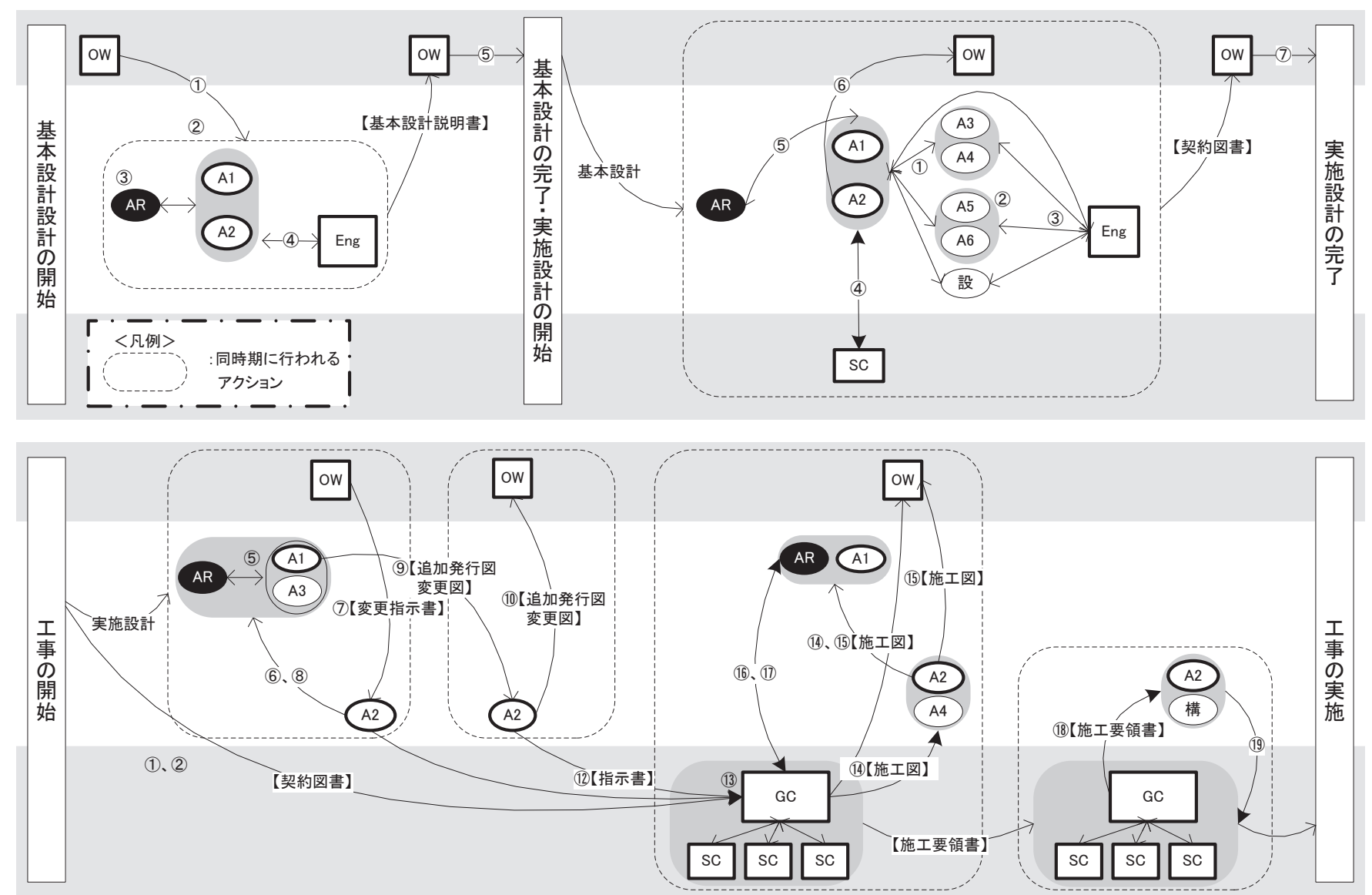

図 2 設計内容の確定過程の概略 
表 4 各アクションの分類

\begin{tabular}{|c|c|c|c|c|c|c|c|c|c|c|}
\hline & \multirow{4}{*}{ アクション } & \multicolumn{7}{|c|}{ 参画主体 } & \multirow{4}{*}{ 設計内容の例 } & \multirow{4}{*}{ 伝達・共有のされ方 } \\
\hline & & \multirow{3}{*}{$\begin{array}{l}\text { 発 } \\
\text { 注 } \\
\text { 者 }\end{array}$} & \multicolumn{4}{|c|}{ 設計者 } & \multirow{3}{*}{$\begin{array}{l}\text { 施 } \\
\text { 管 } \\
\text { 㻎 } \\
\text { 者 }\end{array}$} & \multirow{3}{*}{$\begin{array}{l}\text { 専 } \\
\text { 瞯 } \\
\text { 工事 } \\
\text { 業 }\end{array}$} & & \\
\hline & & & \multicolumn{3}{|c|}{ 前川事務所 } & \multirow{2}{*}{$\begin{array}{l}\text { 横 } \\
\text { 岁 }\end{array}$} & & & & \\
\hline & & & $\begin{array}{l}\text { 前 } \\
\text { 川 }\end{array}$ & $\begin{array}{l}\text { 本 } \\
\text { 社 }\end{array}$ & $\begin{array}{l}\text { 現 } \\
\text { 場 }\end{array}$ & & & & & \\
\hline \multirow{5}{*}{$\begin{array}{l}\text { 基本設計 } \\
\text { 段階 }\end{array}$} & (1) 与条件の提示 & 0 & 0 & 0 & & & & & 全体計画、公募展棟の概要 & \\
\hline & (2) 敷地の見学 & & 0 & 0 & & & & & 配置 & \\
\hline & (3) 四面・スケッチの作成と検討 & & O & O & & & & & $\begin{array}{l}\text { ボリューム、ゾーニング、動線 } \\
\text { 計画 }\end{array}$ & 図面、スケッチ \\
\hline & (4) 構造の検討 & & & 0 & & 0 & & & 階高 & 図面 \\
\hline & (5) 発注者の承認 & $\bigcirc$ & & O & & & & & $\begin{array}{l}\text { 全体計画、動線計画、公募展棟 } \\
\text { の概要 }\end{array}$ & 基本設計説明書 \\
\hline \multirow{7}{*}{$\begin{array}{c}\text { 実施設計 } \\
\text { 段階 }\end{array}$} & (1) 図面の作成 & & & 0 & & & & & 一般図、建具表、詳細図 & 図面 \\
\hline & (2) 先行例の引き継ぎと改善 & & & 0 & & & & & $\begin{array}{l}\text { 打込みタイルや而候性鋼製サ } \\
\text { ッシな゙のディティルル }\end{array}$ & 図面 \\
\hline & (3) 構造・設備の検討 & & & 0 & & 0 & & & & 図面、口頭 \\
\hline & (4) 各部位の検討 & & & 0 & & & & 0 & 打込みタイル & 図面、サンプル \\
\hline & (5) 確認 - 検討 - 指示 & & 0 & 0 & & & & & & 図面、スケッチ、口頭 \\
\hline & (6) 発注者の内諾 & 0 & & 0 & & & & & & 図面 \\
\hline & (7) 発注者の承認 & 0 & & 0 & & & & & 一般図、詳細図、仕上げ & $\begin{array}{l}\text { 契約図書、確認申請用 } \\
\text { 図面 }\end{array}$ \\
\hline \multirow{19}{*}{ 工事段階 } & (1) 設計意図の説明会 & & & & & & & & $\begin{array}{l}\text { 設計上の重要な箇所の説明や、 } \\
\text { 施工上の注意 }\end{array}$ & 口頭 \\
\hline & (2) 先行例の案内と見学 & & & 0 & & & 0 & & 打込みタイル & 実例 \\
\hline & (3) 打ち合わせ & 0 & & & 0 & 0 & 0 & 0 & （疑問点、検討すべき点） & 口頭、施工図 \\
\hline & (4) 定例 & 0 & & 0 & $\mathrm{O}$ & 0 & 0 & & (工事工程) & 口頭、議事録 \\
\hline & (5) 設計内容の追加 ・ 変更 & & O & $\bigcirc$ & & ○ & & & $\begin{array}{l}\text { (詳細、未確定部分、追加、 } \\
\text { 変更) }\end{array}$ & $\begin{array}{l}\text { 追加発行図、変更図、 } \\
\text { 模型 }\end{array}$ \\
\hline & (6) 設計の工程管理 & & & 0 & 0 & & & & (設計工程) & \\
\hline & $\begin{array}{l}\text { (7) 発注者による設計内容の } \\
\text { 追加・変更 }\end{array}$ & 0 & & & O & & & & 部屋の用途 & 変更指示書 \\
\hline & $\begin{array}{l}\text { (8)「現場監理」から「本社監理」 } \\
\text { の坛達 }\end{array}$ & & & 0 & O & & & & (発注者による追加・変更) & \\
\hline & $\begin{array}{l}\text { (9)「本社監理」から「現場監理 } \\
\text { 者」への伝達 }\end{array}$ & & & $\bigcirc$ & O & 0 & & & $\begin{array}{l}\text { (詳細、未確定部分、追加、 } \\
\text { 変更) }\end{array}$ & 追加発行図、変更図 \\
\hline & (10) 発注者の内諾 & 0 & & & 0 & & & & & 追加発行図、変更図 \\
\hline & (11) 工事費の変更（契約変更） & o & & 0 & o & O & O & & & $\begin{array}{l}\text { 変更指示書、追加発行 } \\
\text { 図、変更図、施工図 }\end{array}$ \\
\hline & (12) 監理者から施工者への伝達 & $\bigcirc$ & & & ○ & 0 & 0 & 0 & $\begin{array}{l}\text { 詳細、未確定部分、追加、 } \\
\text { 変更） }\end{array}$ & $\begin{array}{l}\text { 指示書、追加発行図、 } \\
\text { 変更図 }\end{array}$ \\
\hline & (13) 施工図の作成 & & & & & & 0 & 0 & & 施工図 \\
\hline & (14) 施工図の承認 & O & $\bigcirc$ & & O & $\bigcirc$ & O & O & $\begin{array}{l}\text { (設計意図が正確に反映され } \\
\text { ているか、工事予算に合うか) }\end{array}$ & 施工図 \\
\hline & (15) 承認済み施工図の共有・伝達 & 0 & & 0 & 0 & & 0 & 0 & & 施工図 \\
\hline & (16) 現物による検討 & & 0 & 0 & 0 & & 0 & 0 & アーチ & モックアップ、施工図 \\
\hline & (17) 色決め & & $\bigcirc$ & & 0 & & 0 & & 公募展棟の色 & 口頭、例示 \\
\hline & (18) 施工要領書の承認 & & & & $\mathrm{O}$ & 0 & $\bigcirc$ & 0 & （設計意図が実現されるか） & 施工要領書 \\
\hline & (19) 工事の指導 & & & & O & O & O & O & $\begin{array}{l}\text { コンクリート、外壁の打込み } \\
\text { タイル }\end{array}$ & シミュレーション \\
\hline
\end{tabular}

\section{5. 設計対象部位から見た設計内容の確定過程}

\section{5-1 打込みタイル注 16}

(1) 基本設計説明書に、外装には打込みタイルを用いることが記載 された。

(2) 契約図に、打込みタイルを用いる範囲（立面図、断面図、矩計 詳細図 1/50、室内展開図 1/100）が示された。詳細については、『炻 器質タイル標準詳細図』注 ${ }^{17}$ )に外壁用の標淮型 2 種 (A 型、B 型)、 $\mathrm{A}$ 型の変形 3 種、出隅役物右型と左型のほか、一般床用、室内中 木用、彫塑室階段用、空台用のタイルについても形状と寸法が $1 / 2$ で記載された。また、「出隅部分の組合と説明図」には、「全体の A、B 組合とパターンは現場指示とする」と注記されている。こ の時点で、不二致業（専門工事業者）とタイルの色合いと肌につ いて検討が行われた。以前のプロジェクトで用いたタイルの型を 用いて、磁器にするか炻器にするか、土の種類と配合、釉薬の有
無などを検討するためのサンプルが作成され、最終的に前川によ り、タイルの色が確定した。

(3) 前節で示したように、大林組の施工管理者に対して埼玉県立博 物館の案内があり、打込みタイルの具体例が示された。

(4) 経済性から、用いるタイルの種類が減らされた。これを反映し た図面が「本社監理」で作成され、「現場監理」に伝達された。ま た、手戻りを防ぐため、「現場監理」から直接、不二羔業に変更の 指示が出された。

(5) 不二窯業がタイルの原寸図や納まり図（1/2, 1/5)、すべての面 についての展開図を作成した。これらを大林組の施工管理者だけ でなく、前川事務所の「現場監理」の担当者ならびに発注者も承 認した。「現場監理」の担当者、施工管理者、不二窯業の三者での 打ち合わせも行われた。

(6) (5)をふまえ、関連する専門工事業者との打ち合わせを経て大林 
組が施工図を作成した。これを前川事務所の「現場監理」の担当 者が承認した。打込みタイルでは型枠にタイルを張ることから、 型枠に耐力と精度が要求されるため、パネル用の金物が新たに考 案され注 18)、パネルの計画図を横山事務所も承認している注 19)。

(7) 大林組が専門工事業者と共に施工要領書を作成し、施工の流れ や施工時の問題点についてまとめた注 ${ }^{20)}$ 。これを前川事務所と東 京都教育庁に提出し、この承認を以て施工が行われた。

(8) 打込みタイルの工法（栈木工法）も前川事務所と不二倥業の共 同特許であり、例えば、タイルを打ち付けた $1 \mathrm{t}$ 近くの型枠を起こ すことやコーナーの処理など、経験が必要となるため、施工の前 に、「現場監理」の担当者の指導による施工の練習が行われた。外 壁のあるスパンについて、タイル型枠建込み、タイル用目地棒打 付け、型枠面へのタイル打付け、タイル目地モルタルつめ、鉄筋 の組立からコンクリート打設までが実際に行われた。

\section{5-2 耐候性鋼製サッシ【公募棟展出隅空】}

(1) 実施設計を経て、契約図に、耐候性鋼製サッシの位置（建具配 置図、1/200）とその形状、寸法、付属する金物、仕上げ（建具表） が示された。詳細については、『標準詳細図 NO.2 各所出隅空詳 細図』注 ${ }^{21}$ に公募展示室出空詳細図 (平面図、立面図、断面図、 いずれも $1 / 2$ ) が記載された。

(2) 専門工事業者（昭和鋼機）が施工図（平面図、姿図、断面図、 以上いずれも $1 / 20 、 1$ 階足元の納まり、接合部など、いずれも $1 / 1)$ を作成し、大林組の施工管理者が打込みタイルとの取り合いなど、 他の部分との関係をチェックし、前川事務所に承認願を出した。 サッシに関しての承認は、前川自身が行った。

(3) 前川之「本社監理」の担当者 2 名、「現場監理」の担当者 1 名、 施工管理者が工場検查に行き、仮組立の出来上がった現物を見て 検討を行った。その結果、前川の指示により、ディティールが再 検討され、「本社監理」の担当者が図面を作成した。その図面によ って、前川の承認を得た。

\section{$5-3$ 手すり【大彫塑室】}

(1) 契約図の平面詳細図（1/200）に手すりをつける䇢所が示され、

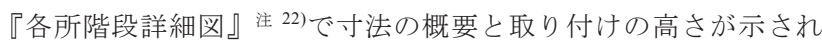
た。

(2) 追加発行図の『大彫塑室廻り手スリ・壁・変更図』注 ${ }^{23}$ におい て、展開図（1/200）で手すりの形状、仕上げが示された。

(3) 専門工事業者が作成した施工図において、原寸図で平断面詳細 図、断面詳細図、持出し部分断面詳細が描かれ、施工管理者、前 川事務所の「現場監理」の担当者が承認した。

\section{6. まとめ}

本稿では、設計者が建築プロセスの各段階で建築プロジェクトの 参加者と連携して業務を進めた典型例として、前川國男建築設計事 務所の設計による東京都美術館を取り上げ、文献調查、資料調查、 プロジェクトに参加した設計者・施工者へのヒアリング調査にもと づき、建築プロセスにおける体制の推移と設計内容の確定の流れ、 設計対象部位から見た設計内容の確定過程について実証的に明示し、 図表化を行った。

以上により、東京都美術館の建築プロセスにおいては、(1)実施設 計段階における、共同で技術を開発した専門工事業者の参加や、基
本設計から参加した設計者が、現場で施工管理者・専門工事業者に 設計意図を伝達するなどの、デザインの完成度を上げるための連携、 (2)基本設計段階からの構造設計者との参加や、監理者による工事の 指導などの、物理的な品質を確保するための連携、(3)タイルの種類 の変更などの、工期・コストを守るための連携が行われたことが確 認された。

今後の研究においては、他の建築プロジェクトについて検討する と共に、本稿とあわせ、設計内容の確定過程における多様な方法や 共通する要素について考察することを課題としたい。また、社会や 法制度の変化する中で、本稿のような建築プロセスが、建築家の弟 子の世代にはどのように受け継がれ、またはどのように改変・展開 されているのかについても、検討を加えたい。

\section{謝辞}

本論文は、科学研究費（基盤 $\mathrm{A}$, 代表 : 古阪秀三）の助成を受け た。東京都美術館の調查にあたっては、同プロジェクトの担当者で ある、元前川國男建築設計事務所（現前川建築設計事務所）所員の 高橋義明氏、川島一夫氏、大林組の瀬藤素直氏に貴重な話をお聞か せいただいた。また、前川建築設計事務所の橋本功氏、東原克行氏、 大林組の姉崎哲朗氏、元日建設計の橋本喬行氏、日本建築士会連合 会の峰政克義氏には、研究全体に関わるご助言とご協力をいただい た。この場を借りて厚く御礼申し上げます。

注

注 1) 国土交通省告示第十五号（2009 年 1 月）、別添一、1 設計に関する標準 業務、三工事施工段階で設計者が行うことに合理性がある実施設計に関す る標準業務に、「設計意図を正確に伝えるための質疑応答、説明等」、「工事 材料、設備機器等の選定に関する設計意図の観点からの検討、助言等」が 挙げられている。

注 2）意匠・構造・設備の設計者、施工者、研究者をメンバーとする、協調 型設計・業務モデル研究会（代表 : 古阪秀三，京都）における、2008 年 6 月から 2009 年 10 月の、のべ 12 回の議論による。

注 3) 学術講演としては、乙村雅人ほか：前川國男の美術館・博物館に関寸 る研究(1)一9 作品のロビー空間における空間構成の特徴一, 日本建築学会 学術梗概講演集（中国），pp.449 450，2008.9、神部聡ほか：埼玉県立博物 館の設計過程, 日本建築学会学術梗概講演集（関東), pp.757 756, 2006.9 などがある。

注 4) 東京都美術館の担当者である、元前川國男建築設計事務所所員の高橋 義明氏、川島一夫氏、大林組の瀬藤素直氏に、2009 年 1 月から 2010 年 4 月の間に、下記の通りヒアリング調査を行った。高橋氏と川島氏のヒアリ ングにあたっては、前川建築設計事務所所長の橋本功氏ならびに同副所長 の東原克行氏、瀬藤氏のヒアリングにあたっては、大林組の姉崎哲朗氏に アドバイザーとしてご臨席いただいた。

(1) 2009 年 1 月 28 日：高橋氏、川島氏、橋本氏、東原氏（聞き手：西野、 古阪)、於前川建築設計事務所

(2) 2009 年 1 月 28 日：瀬藤氏、姉崎氏（西野、古阪）、於大林組東京本店

(3) 2009 年 9 月 7 日：瀬藤氏、姉崎氏 (西野、古阪、平野)、於大林組東京 本店

(4) 2009 年 9 月 11 日：高橋氏、川島氏、橋本氏、東原氏（西野、古阪、平 野)、於前川建築設計事務所

(5) 2010 年 2 月 8 日：川島氏、橋本氏（西野、古阪、平野）、於前川建築設 計事務所

(6) 2010 年 4 月 4 日：高橋氏、東原氏 (西野)、於東京都美術館 なお、高橋氏、川島氏への電話による追加調查（2009 年 11 月 5 日、2010 年 4 月 2 日、 24 日）ならびに 2010 年 4 月 4 日に東京都美術館において開 
催された「おや寸夕都美館建築講座」における高橋氏、川島氏、橋本氏、 東原氏へのインタビューも参照した。

注 5) このような手法を理論的サンプリングといい、B.G. グレイザーほか : データ対話型理論の発見 調査からいかに理論をうみだすか, 新曜社, 1996 や佐藤郁哉：定性デー夕分析入門，新曜社，2006 などに詳しい。

注 6) 代表作に、下記のほか、紀伊國屋ビルディング(1964)、埼玉会館(1966)、 熊本県立美術館（1977）など。

注 7) 日本相互銀行本店（1953 年度）、神奈川県立図書館・音楽堂（1955 年 度)、京都会館（1961 年度）、東京文化会館（1962 年度）、蛇の目ミシン工 業本社ビル（1966 年度）。なお、坂倉準三・吉村順三との協同設計で、国 際文化会館でも受賞している(1956 年度)。

注 8) 日本建築士会連合会：監理業務と瑕疪担保，日本建築士会連合会， 1984.12 では、設計監理について、「これは設計と監理という意味ではなく、 監督或いは工事監理に対して、設計者の行う設計の延長としての監理とい う意味で用いられている」と述べられている（p.3）。

注 9) ヒアリングによれば、電気の担当者と入れ替わりに空調・衛生の担当 者が常駐したので、設備の担当者としては、建築プロセスを通して 1 人工 が常駐した。

注 10) 例えば土工事について、『床付・敷砂利計画』(東京都美術館改築工事 施工記録, pp.115 116)

注 11) 工事データー 東京都美術館「B 設計概要」

注 12) 設備については別途工事であったため、今回の調査で収集した、大林 組が保管していた契約図には、設備図は含まれていない。

注 13) 工事データー 東京都美術館「B 設計概要」

注 14) 川島氏が保管されている追加発行図・変更図の縮小版による。

注 15) 大林組の「東京都美術館改築工事 建築生産設計図デー夕」による。

注 16）橋本氏によれば、打込みタイル、耐候性鋼、PC コンクリートは「前川 御三家」と称される特徴的な要素であり、いずれも前川事務所と専門工事 業者（打込みタイル：不二攽業、耐候性鋼：昭和鋼機、 $\mathrm{PC}$ コンクリート： 湊建材）が協㗢で開発したもので、同事務所による豊富な実用例を通して ディティールや技術が蓄積されている。なお、打込みタイルは「コンクリ

一ト壁体構築法」として、前川事務所と不二窯業が特許を取っている。

注 17) 契約図、図面番号 A-145

注 18）東京都美術館改築工事施工記録、p.173，pp.183 184

注 19) 同上、pp.181 182

注 20) 同上、pp.269 276

注 21) 契約図、図面番号 A-144

注 22) 同上、図面番号 A-136

注 23) 設計変更図・追加発行図、図面番号 A-261

\section{参考文献}

1）高麗一大他：品質事故事例からみる建築生産システムの実態とその脆弱 性, 日本建築学会計画系論文集, 第 73 巻, 第 623 号, pp.183 190, 2008.1

2) 平野吉信他 : 建築プロジェクト組織の重層構造の実態と品質碓保の仕組 みの構築に関する研究, 日本建築学会 第 23 回建築生産シンポジウム (東 京）論文集, pp.287 292, 2005.7

3）古阪秀三他：日本の建築プロジェクトにおける品質確保のしくみとほこ ろびモデル一品質確保のしくみの日中韓台比較の準備作業として一，日中 韓台の建設産業における法制度と品質確保のしくみに関する比較研究 第 1 回研究発表会（京都）論文集, pp.59 65, 2008.7

4) 峰政克義他 : 建築プロジェクトにおける生産情報の確定過程, 日本建築 学会計画系論文集, 第 502 号, pp.187 194, 1997.12、峰政克義他：建築プ ロジェクトにおける生産情報の共有と整合のしくみ, 日本建築学会計画系 論文集，第 504 号，pp.179 186，1998.2、など

5) 東京都美術館 BCS 賞受賞作品探訪記 12，築，No.27，pp.20 29，2007.5

6) 東京都美術館編 : 東京都美術館 80 周年記念誌 記憶と再生 Reminiscence and Renaissance 1926-2006，東京都美術館，2007

7）東京都美術館，新建築，Vol.52，No.1，pp.187 202，1977.1、東京都美術 館, 建築文化, Vol.32, No.363，pp.93 100，1977.1、東京都美術館，近代 建築, Vol.31, No.4, pp.25 36, 1977.4、など
8) 前川國男, 宮内嘉久編：一建築家の信條，晶文社，1981

9) 前川國男, 前川國男文集編集委員会編: 建築の前夜一前川國男文集, 而 立書房, 1996

10) 宮内嘉久編：前川國男作品集一建築の方法, 美術出版社, 1990

11）前川國男・MID 同人：前川國男のディテール（熊本県立美術館をとおし て), 彰国社, 1979

12）川添登ほか監修: 東京文化会館／前川國男 世界建築設計図集 6, 同朋舎 出版, 1984

13) 宮内嘉久: 前川國男 賊軍の将, 晶文社, 2005

14）前川國男建築設計事務所 $\mathrm{OB}$ 会有志：前川國男・弟子たちは語る, 建築 思潮研究所, 2006

15) 松隈洋編：前川國男 現代との対話，六耀社，2006

16）日本建築士会連合会：品質管理をベースとした新しい建築生産のしくみ 一施工管理と工事監理への一提案一, 日本建築士会連合会, 1986

17）建築業協会：建築工事における品質情報伝達のしくみとツール一新しい 建築生産体制への提案一，建築業協会，1988

18）建築業協会 : 建築工事における『品質情報伝達のしくみとツール』の実 践一向けて, 建築業協会, 1992

19）日本建築士会連合会 : 設計と施工を結ぶ一新しい建築生産に対応した品 質情報伝達の提案一, 日本建築士会連合会, 1994

20）建築業協会 : 建築工事における『品質情報伝達のしくみとッール』の実 践一向けて一その 2 設計者・施工者の役割分担の提案一, 建築業協会, 1995

21）新日本建築家協会 JIA : 設計情報伝達の向上を目指して一実施設計図から 施工図一の展開一, 新日本建築家協会, 1996

22) 座談会 前川國男の世界 テクニカルアプローチについて, 特集 前川 國男が遺したもの, Glass and Architecture, No.363, pp.4 9, 1988.6

23) 松隈洋: 前川國男とテクニカル・アプローチ, 建築家 前川國男の仕事, p.122，美術出版社，2006

（2009年11月10日原稿受理，2010年 4 月30日採用決定） 